Agro-Science Journal of Tropical Agriculture, Food, Environment and Extension Volume 18 Number 3 (September 2019) pp. 5-10

ISSN 1119-7455

\title{
ASSESSING THE LENGTH OF GROWING SEASON IN THE SUDAN SAVANNA ECOLOGICAL ZONE OF NIGERIA AS A CHALLENGE TO FOOD SECURITY FOR SUSTAINABLE DEVELOPMENT
}

\author{
"Haruna S. and Murtala M.R. \\ Department of Geography, Umaru Musa Yar`adua University, Katsina, Katsina State, Nigeria \\ *Corresponding author's email: haruna.saleh@umyu.edu.ng
}

\begin{abstract}
Since the inception of the present Government in May 2015, it has been battling with socio-economic problems ranging from economic recession, fall of crude oil prices in the international markets and insecurity challenge, among others. To achieve sustainable development goals, Government focused on agriculture as the best option for tackling such problems. It is against this background that this paper aimed at assessing the length of growing season in the Sudan Savanna Ecological Zone of Nigeria using daily rainfall data recorded at nearby stations from 1981 to 2010. It assessed the level and mean length of growing season in Kano, Katsina, Maiduguri, Potiskum, Gusau and Sokoto, all of which are located within this ecological zone. Data analysis involved the use of descriptive statistics to compute cumulative pentade rainfall and ogive of cumulative pentade rainfall. Using pentade and Julian day calendars, an annual ogive of cumulative pentade rainfall was drawn using Microsoft Excel for each study location and length of growing season determined from 1981 to 2010. Results obtained indicate that mean length of growing season for the study area was approximately 125 days, a duration that is slightly longer than four months. To achieve sustainable development in agriculture, the study recommends that agricultural policies in the study area should take into consideration the rather short mean length of growing season in the study area while exploring effective and feasible water conservation techniques to complement rainwater.
\end{abstract}

Key words: assessment, growing season length, Sudan savanna, Nigeria

\section{INTRODUCTION}

Length of growing season is defined as the period of the year during which rainfall distribution characteristics are suitable for crop germination and full development (Odekunle, 2004). It is a period of the year categorized as rainy or wet season. The length of the growing season varies spatially and temporally. The length of growing season can be determined, for each year, by subtracting the date at which the rains start from the date that the rains end (Madeoye, 1986; Zargina, 1987). Oladipo and Kyari (1993) in their study of growing season rainfall of Northern Nigeria indicated that the onset, cessation and length of growing season showed latitudinal progress but with some disruptions due to geographic effect in the central area (Jos). Adefolalu (1993) stated that the length of the growing season is obtained by subtracting the onset pentade from the cessation pentade and multiplying by five. Aliyu (2009) observed a downward trend in the duration (length) of the growing season in some locations in northern Nigeria from 1978 to 2007, with a significant variability in most of the stations north of latitude $9^{\circ} \mathrm{N}$ in Nigeria. Odekunle (2004) also observed that rainfall during the crop-growing season determines crops germination, establishment and full development. He further defined growing season as period between onset and cessation of the rains.
The length of the growing season (days) for a particular year is considered as the difference between the Julian day number of the determined cessation date and determined onset for that year. Studies conducted in semi-arid parts of West Africa indicated that there is a significant relationship between the start of rains and the length of growing season (Shevakuma, 1988). Thus, earlier onset most often leads to longer length of growing season and late onset shorter length of growing season. This is an indication that the length of growing season is more dependent on rainfall onset than on its cessation (Omotosho, 1992). The length of growing season often determines which crops could grow in an area, as some crops require long growing seasons, while others mature rapidly. Among researchers that have emphasized linkages of the growing season with reliable onset of rains are Dagg (1965), Bello (1996), Olaniran (1984), Ati et al. (2002), and Sawa and Ibrahim (2011).

The unreliable knowledge of length of growing season in the Sudan Savanna Ecological Zone of Nigeria often causes a great threat to agricultural productivity. Most a time crops are grown without considering temporal and spatial variations of length of growing season; this practice often leads to poor yields. The aim of this paper was, therefore, 
to assess the length of growing season in Kano, Katsina, Maiduguri, Potiskum, Sokoto and Gusau. The aim was achieved by the following objectives (i) to determine the level of length of growing season from 1981 to 2010 in each study location, and (ii) to assess the mean length of growing season in each study location and the study area in general.

\section{MATERIALS AND METHODS \\ Study Area}

The study area was Sudan Savannah Ecological Zone of Nigeria. It lies between Latitudes $100^{\circ}$ and $120^{\circ} \mathrm{N}$ and Longitudes $40^{\circ}$ and $150^{\circ} \mathrm{E}$ (Fig. 1). It stretches from the Sokoto plains in the west through the northern section of the high plains of northern Nigeria in the east to the Chad Basin. It thus includes the states of Kaduna, Katsina, Kano, Jigawa, Zamfara, Sokoto, Kebbi, and Borno.

\section{Study Locations}

Six locations were chosen for this study. They included Kano, Katsina, Maiduguri, Potiskum, Sokoto and Gusau in the Sudan savanna climatic zone. The locations were chosen based on availability of meteorological stations within the zone. These meteorological stations are synoptic stations that have long period of daily rainfall records. They are consistent in location since their establishment; have no significant missing rainfall records and geographically well distributed within the area.

\section{Types of Data Needed}

In this type of empirical study, daily rainfall records are required. The analysis covers the growing season - 1st May to 31st October, for this is the period when all the stations in this climatic zone receive about $95 \%$ of their total annual rainfall (Anyadike, 1992).

\section{Sources of Data}

Daily rainfall data for each of the six locations sourced from the Nigerian Meteorological Agency (NIMET) Oshodi, Lagos. Oshodi was the headquarters of this agency that kept meteorological data for all meteorological stations across Nigeria. The records of rainfall used are shown in Table 1.

\section{Derivation of the Level and Mean Length of Growing Season}

Daily rainfall data for the period 1981-2010 for the six locations were sourced from NIMET, Oshodi, Lagos. These data were used to derive the level and mean length of growing season based on onset and cessation dates of rains. A method used by Adefolalu (1993) which was based on relative definition was adopted to derive the level and mean length of growing season in the study area. Using this method, the onset and cessation dates of rains were determined by dividing each year into pentades, making 72 pentades. Using pentade calendar (Table 2), cumulative pentades rainfall was then calculated for each year in the study period 1981-2010. Cumulative pentade rainfall was plotted against the number of pentades giving an ogive for each year in the study area. The points on the pentade axis corresponding to the first and last points of the maximum inflexion on the rainfall ogive correspond to the onset and cessation pentades, respectively. The last date in the onset pentade gives the exact onset date and the first date in the cessation pentade gives the cessation date of the rainy season. The gap between onset and cessation pentades gives the length of growing season.

The derived onset and cessation dates were then converted to Julian days using Julian day calendar and used to obtain the length of growing season of each year in the study period. The Julian day calendar has regular year of 365 days divided by 12 months. A leap year which occurs once every four years adds one day to February. A leap year thus has 366 days including 29 February as an intercalary day. The Julian year is, therefore, on average of 365.25 day long. This method was used in the derivation of length of growing season in the study area. The method utilizes daily rainfall data that makes it more accurate and precise method for determining the length of growing season. The typology of this method at Kano and Katsina in 1981 is presented in Figs. 2 and 3. The data presented in Fig. 2 reveal that the onset pentade falls on pentade 29 and the onset date of rainfall corresponds to 21-May 1981 (Table 2).

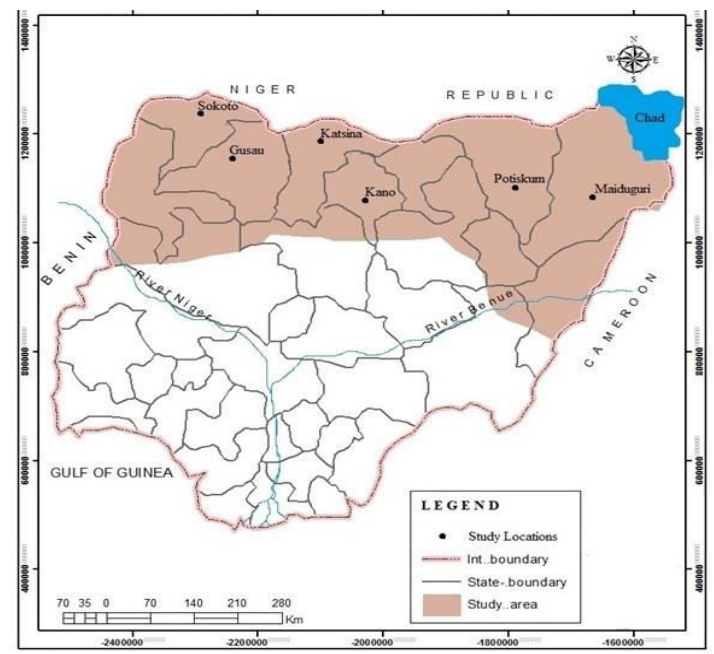

Fig. 1: Study area showing the location of study sites. Source: Les Edition (2006)

Table 1: Rainfall in the study area

\begin{tabular}{ll}
\hline Location & Rainfall \\
\hline Gusau & 30 years $(1981$ to 2010$)$ \\
Kano & 30 years $(1981$ to 2010$)$ \\
Katsina & 30 years $(1981$ to 2010$)$ \\
Maiduguri & 30 years $(1981$ to2010) \\
Potiskum & 30 years $(1981$ to 2010$)$ \\
Sokoto & 30 years $(1981$ to 2010$)$ \\
\hline Source: NIMET (2013) &
\end{tabular}




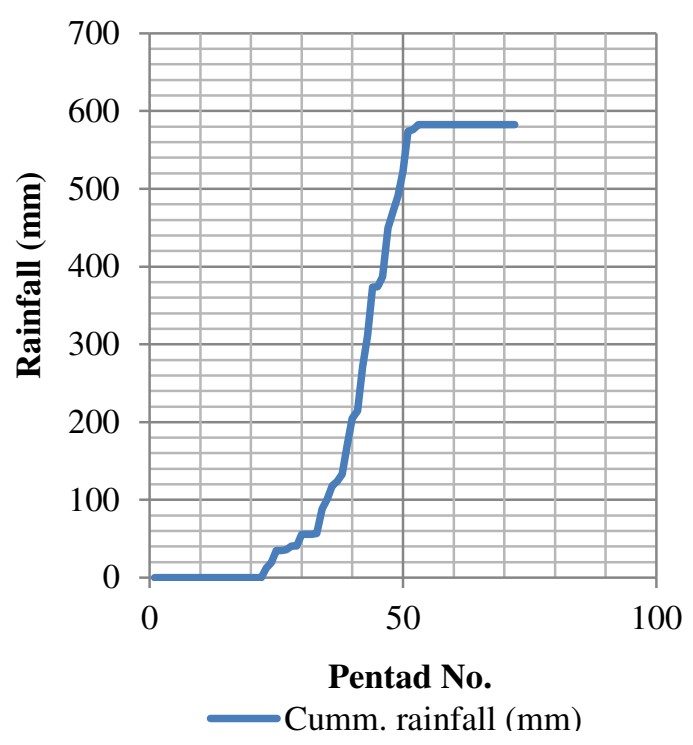

Fig. 2: Ogive of cumulative pentade rainfall at Kano (1981) for determination the level and mean length of growing season

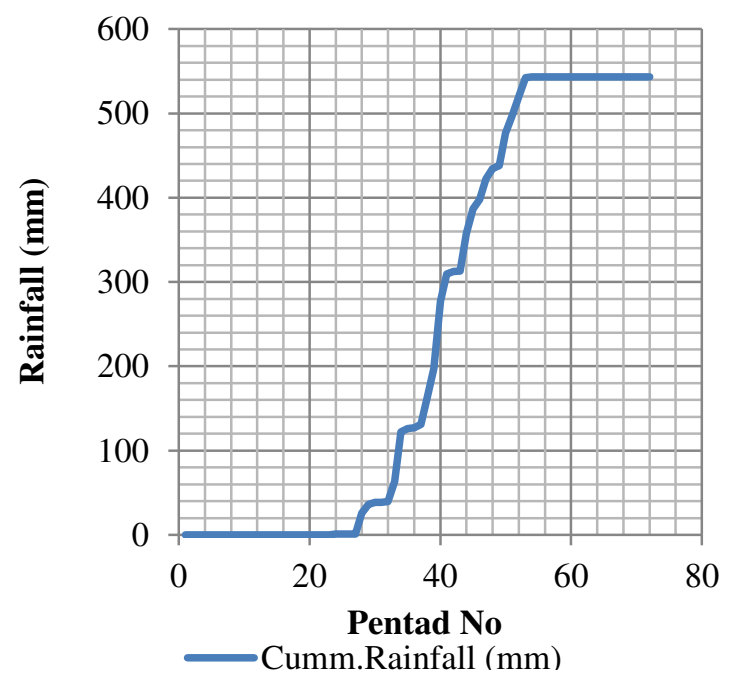

Fig. 3: Ogive of cumulative pentade rainfall at Katsina (1981) for determination of the level and mean of length of growing season

The cessation pentade falls on pentade 53 and the cessation date of rainfall corresponds to 25September 1981 (Table 2). Using Julian day and pentade calendar, the length of growing season at Kano in 1981 was 156 days (Table 3). Data shown in Fig. 3 indicate that the onset pentade falls on pentade 30 and the onset date of rainfall corresponds to 26-May in 1981 (Table 2). The cessation pentade falls on pentade 53 and the cessation date of rainfall corresponds to 25-September in 1981 (Table 2). Using Julian day and pentade calendar, the length of growing at Katsina in 1981 was 136 days (Table 4). The other onset and cessation dates and length of growing season for the study period in each location were obtained in similar manner using Julian day and pentade calendars.

\section{RESULTS AND DISCUSSION}

The Level and Mean Length of Growing Season Results on the level and mean length of growing season in days for the study locations in the study period from 1981 to 2010 are presented in Tables $3,4,5,6,7$ and 8 . It could be observed that both the levels and mean lengths of growing season vary among the study locations.

In Table 3 (Kano station), the mean length of growing season was 133 days. At Katsina (Table 4), the mean length of growing season was 121 days. In Maiduguri, station (Table 5) the mean length of growing season was 120 days. In Table 6 (Potiskum station), the mean length of growing was 121 days. At Sokoto (Table 7), the mean length of growing season was 120 days. At Gusau (Table 8), the mean length of growing season was 133 days. In 1981 the level of length growing season was 156 days at Kano, 136 days at Katsina, 117 days at Maiduguri, 161 days at Potiskum, 130 days at Sokoto and 135 days at Gusau, respectively. Computing the mean length of growing season of the study locations indicates that the mean length of growing season for Sudan Savanna Ecological Zone of Nigeria is approximately 125 days. Data presented in Table 3 reveal variation in the level of length of growing season at Kano in the period of study from 1981 to 2010 . The longest length of growing season of 181 days was recorded in 2010 and the shortest of 85 days in 1994. The mean length of growing season for the location was 133 days.

It could be observed from the data presented in Table 4 that the longest length of growing season recorded was in 2009 with 151 days. The shortest length of growing season was in 1993 with 90 days. The mean length of growing season for the study location was 121 days. Data presented in Table 5 indicate that the longest length of growing season was in 2005 with 151 days. The shortest one was in 1986 with 85 days and was the driest year in the period of study. The mean length of growing season for the location was 120 days. It could be observed from the data presented in Table 6 that the longest length of growing season in this location in the study period was 161 days in 1981 . The shortest length of growing season occurred in 1993 and 1983 with 70 days and 76 days, respectively. These are the driest years in the period of study. Data presented in Table 7 reveal that the longest length of growing season at Sokoto was in 1997 with 166 days. The shortest length of growing season was in 1996, 1986 and 1992 with 90, 95, and 95 days, respectively. Data presented in Table 8 indicate that the level of length of growing season varied among the years in the study period. For instance, the level of length of growing season was 135 days in 1981, 141 days in 1982, and 151 days in 1991. The longest length of growing in this location was in 2010 with 182 days and the shortest in 1999 with 59 days. The linear distribution of mean length of growing season for the study locations is presented in Fig. 4. 
Table 2: Pentade calendar

\begin{tabular}{|c|c|c|c|c|c|c|c|}
\hline \multicolumn{2}{|l|}{ JANUARY } & \multicolumn{2}{|l|}{ FEBRUARY } & \multicolumn{2}{|l|}{ MARCH } & \multicolumn{2}{|l|}{ APRIL } \\
\hline Pentade No. & Dates & Pentade No. & Dates & Pentade No. & Dates & Pentade No. & Dates \\
\hline 1 & $1^{\text {st }}-5^{\text {th }}$ & 7 & $1^{\text {st }}-5^{\text {th }}$ & 13 & $1^{\text {st }}-5^{\text {th }}$ & 19 & $1^{\mathrm{st}}-5^{\mathrm{th}}$ \\
\hline 2 & $6^{\text {th }}-10^{\text {th }}$ & 8 & $6^{\text {th }}-10^{\text {th }}$ & 14 & $6^{\text {th }}-10^{\text {th }}$ & 20 & $6^{\text {th }}-10^{\text {th }}$ \\
\hline 3 & $11^{\text {th }}-15^{\text {th }}$ & 9 & $11^{\text {th }}-15^{\text {th }}$ & 15 & $11^{\text {th }}-15^{\text {th }}$ & 21 & $11^{\text {th }}-15^{\text {th }}$ \\
\hline 4 & $16^{\text {th }}-20^{\text {th }}$ & 10 & $16^{\text {th }}-20^{\text {th }}$ & 16 & $16^{\text {th }}-20^{\text {th }}$ & 22 & $16^{\text {th }}-20^{\text {th }}$ \\
\hline 5 & $21^{\mathrm{st}}-25^{\mathrm{th}}$ & 11 & $21^{\mathrm{st}}-25^{\mathrm{th}}$ & 17 & $21^{\mathrm{st}}-25^{\mathrm{th}}$ & 23 & $21^{\mathrm{st}}-25^{\mathrm{th}}$ \\
\hline 6 & $26^{\mathrm{th}}-31^{\mathrm{st}}$ & 12 & $26^{\text {th }}-28^{\text {th }}$ & 18 & $26^{\text {th }}-31^{\text {st }}$ & 24 & $26^{\text {th }}-30^{\text {th }}$ \\
\hline MAY & & JUNE & & JULY & & AUGUST & \\
\hline Pentade No. & Dates & Pentade No. & Dates & Pentade No. & Dates & Pentade No. & Dates \\
\hline 25 & $1^{\text {st }}-5^{\text {th }}$ & 31 & $1^{\text {st }}-5^{\text {th }}$ & 37 & $1^{\mathrm{st}}-5^{\mathrm{th}}$ & 43 & $1^{\text {st }}-5^{\text {th }}$ \\
\hline 26 & $6^{\text {th }}-10^{\text {th }}$ & 32 & $6^{\text {th }}-10^{\text {th }}$ & 38 & $6^{\text {th }}-10^{\text {th }}$ & 44 & $6^{\text {th }}-10^{\text {th }}$ \\
\hline 27 & $11^{\text {th }}-15^{\text {th }}$ & 33 & $11^{\text {th }}-15^{\text {th }}$ & 39 & $11^{\text {th }}-15^{\text {th }}$ & 45 & $11^{\text {th }}-15^{\text {th }}$ \\
\hline 28 & $16^{\text {th }}-20^{\text {th }}$ & 34 & $16^{\text {th }}-20^{\text {th }}$ & 40 & $16^{\text {th }}-20^{\text {th }}$ & 46 & $16^{\text {th }}-20^{\text {th }}$ \\
\hline 29 & $21^{\mathrm{st}}-25^{\mathrm{th}}$ & 35 & $21^{\mathrm{st}}-25^{\text {th }}$ & 41 & $21^{\text {st }}-25^{\text {th }}$ & 47 & $21^{\text {st }}-25^{\text {th }}$ \\
\hline 30 & $26^{\text {th }}-31^{\text {st }}$ & 36 & $26^{\text {th }}-30^{\text {th }}$ & 42 & $26^{\text {th }}-31^{\text {st }}$ & 48 & $26^{\text {th }}-31^{\text {st }}$ \\
\hline SEPTEMBER & & OCTOBER & & NOVEMBER & & DECEMBER & \\
\hline Pentade No. & Dates & Pentade No. & Dates & Pentade No. & Dates & Pentade No. & Dates \\
\hline 49 & $1^{\text {st }}-5^{\text {th }}$ & & $1^{\mathrm{st}}-5^{\text {th }}$ & 61 & $1^{\text {st }}-5^{\text {th }}$ & 67 & $1^{\text {st }}-5^{\text {th }}$ \\
\hline 50 & $6^{\text {th }}-10^{\text {th }}$ & 56 & $6^{\text {th }}-10^{\text {th }}$ & 62 & $6^{\text {th }}-10^{\text {th }}$ & 68 & $6^{\text {th }}-10^{\text {th }}$ \\
\hline 51 & $11^{\text {th }}-15^{\text {th }}$ & 57 & $11^{\text {th }}-15^{\text {th }}$ & 63 & $11^{\text {th }}-15^{\text {th }}$ & 69 & $11^{\text {th }}-15^{\text {th }}$ \\
\hline 52 & $16^{\text {th }}-20^{\text {th }}$ & 58 & $16^{\text {th }}-20^{\text {th }}$ & 64 & $16^{\text {th }}-20^{\text {th }}$ & 70 & $16^{\text {th }}-20^{\text {th }}$ \\
\hline 53 & $21^{\mathrm{st}}-25^{\text {th }}$ & 59 & $21^{\text {st }}-25^{\text {th }}$ & 65 & $21^{\text {st }}-25^{\text {th }}$ & 71 & $21^{\text {st }}-25^{\text {th }}$ \\
\hline 54 & $26^{\text {th }}-30^{\text {th }}$ & 60 & $26^{\text {th }}-31^{\text {st }}$ & 66 & $26^{\text {th }}-30^{\text {th }}$ & 72 & $26^{\text {th }}-31^{\text {st }}$ \\
\hline
\end{tabular}

Table 3: The level and mean length of growing season at Kano from 1981 to 2010

\begin{tabular}{lc}
\hline Years & Length of growing season (days) \\
\hline 1981 & 156 \\
1982 & 141 \\
1983 & 116 \\
1984 & 161 \\
1985 & 146 \\
1986 & 110 \\
1987 & 125 \\
1988 & 115 \\
1989 & 110 \\
1990 & 90 \\
1991 & 131 \\
1992 & 131 \\
1993 & 116 \\
1994 & 85 \\
1995 & 131 \\
1996 & 146 \\
1997 & 151 \\
1998 & 156 \\
1999 & 136 \\
2000 & 136 \\
2002 & 115 \\
2003 & 131 \\
2004 & 116 \\
2005 & 136 \\
2006 & 161 \\
2008 & 141 \\
2009 & 161 \\
Mean & 130 \\
\hline Source: & 115 \\
1090 & 181 \\
& 133 \\
\hline
\end{tabular}

Source: Data Analysis, 2013

The results in Tables 3 to 8 have implications on the basic agrometeorological information needed before planting for necessary pre-sowing activities, such as land preparation, fertilizer and crop species selection in the study locations. Species of droughttolerant crops should be planted in this ecological zone. This is because each location showed a short mean length of growing season of ca. four months during the period under study. This observation is less by one month compared with that of Anyadike (1992) who reported that all stations in the Sudan
Table 4: The level and mean length of growing season at Katsina from 1981 to 2010

\begin{tabular}{cc}
\hline Years & Length of growing season (days) \\
\hline 1981 & 136 \\
1982 & 130 \\
1983 & 101 \\
1984 & 125 \\
1985 & 136 \\
1986 & 91 \\
1987 & 120 \\
1988 & 120 \\
1989 & 125 \\
1990 & 110 \\
1991 & 146 \\
1992 & 125 \\
1993 & 90 \\
1994 & 110 \\
1995 & 105 \\
1996 & 125 \\
1997 & 130 \\
1998 & 125 \\
1999 & 105 \\
2000 & 130 \\
2001 & 115 \\
2002 & 115 \\
2003 & 141 \\
2004 & 136 \\
2005 & 110 \\
2006 & 110 \\
2007 & 130 \\
2008 & 120 \\
2009 & 151 \\
2010 & 105 \\
Mean & 121 \\
\hline Source: Data Analysis 2013 &
\end{tabular}

climatic zone received ca. 95\% of their total annual rainfall in the growing season within 5 months from $1^{\text {st }}$ May to $31^{\text {st }}$ October. This shows that length of growing season differs from total annual rainfall. In Odekunle's (2004) concept, rainfall in the length of growing season determines crop germination, establishment and full development. Therefore, effective and feasible water conservation techniques in the study locations should be explored (Obalum et al., 2011), as such 'saved' water could complement rainfall in crop production in the area. 


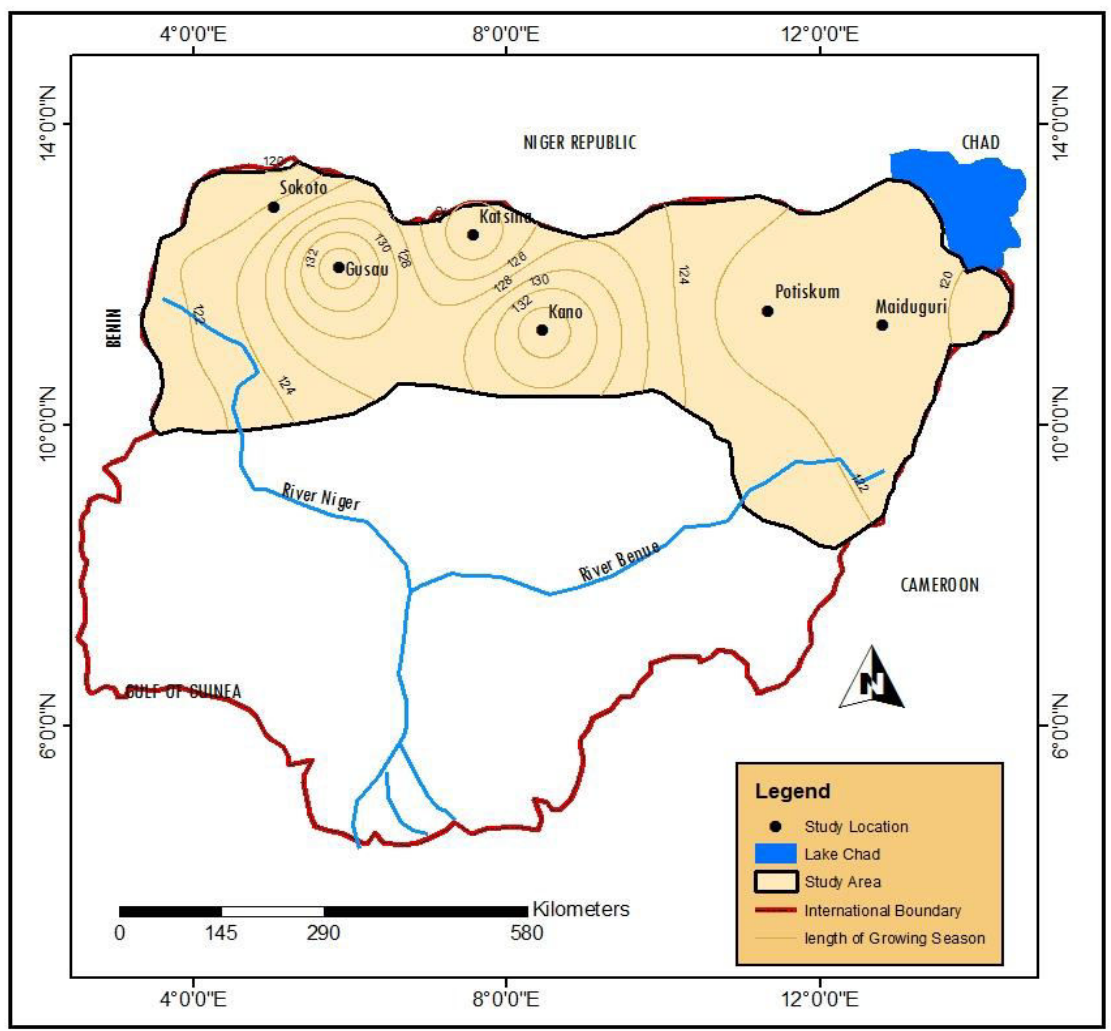

Fig. 4: Linear distribution of mean length of growing season for the study locations

Table 6: the level and mean length of growing season (LGS) at Potiskum from 1981 to 2010

\begin{tabular}{cc}
\hline Years & LGS (Days) \\
\hline 1981 & 161 \\
1982 & 115 \\
1983 & 76 \\
1984 & 105 \\
1985 & 125 \\
1986 & 120 \\
1987 & 125 \\
1988 & 105 \\
1989 & 161 \\
1990 & 105 \\
1991 & 146 \\
1992 & 95 \\
1993 & 70 \\
1994 & 120 \\
1995 & 110 \\
1996 & 151 \\
1997 & 146 \\
1998 & 115 \\
1999 & 115 \\
2000 & 95 \\
2001 & 110 \\
2002 & 115 \\
2003 & 141 \\
2004 & 125 \\
2005 & 135 \\
2006 & 141 \\
2007 & 90 \\
2008 & 156 \\
2009 & 135 \\
2010 & 125 \\
Mean & 121 \\
\hline Source: Data Analysis, 2013 \\
\end{tabular}

Table 7: the level and mean length of growing season (LGS) at Sokoto from 1981 to 2010

\begin{tabular}{cc}
\hline Years & LGS (Days) \\
\hline 1981 & 130 \\
1982 & 115 \\
1983 & 100 \\
1984 & 100 \\
1985 & 100 \\
1986 & 95 \\
1987 & 151 \\
1988 & 110 \\
1989 & 115 \\
1990 & 95 \\
1991 & 135 \\
1992 & 95 \\
1993 & 126 \\
1994 & 105 \\
1995 & 105 \\
1996 & 90 \\
1997 & 166 \\
1998 & 126 \\
1999 & 105 \\
2000 & 146 \\
2001 & 125 \\
2002 & 120 \\
2003 & 146 \\
2004 & 141 \\
2005 & 126 \\
2006 & 120 \\
2007 & 135 \\
2008 & 110 \\
2009 & 110 \\
2010 & 157 \\
Mean & 120 \\
\hline Source: Data Analysis, 2013 \\
& \\
& \\
& 135 \\
&
\end{tabular}

Table 8: The level and mean length of growing season (LGS) at Gusau from 1981 to 2010

\begin{tabular}{cc}
\hline Years & LGS (Days) \\
\hline 1981 & 135 \\
1982 & 141 \\
1983 & 105 \\
1984 & 151 \\
1985 & 135 \\
1986 & 110 \\
1987 & 95 \\
1988 & 130 \\
1989 & 120 \\
1990 & 125 \\
1991 & 151 \\
1992 & 157 \\
1993 & 130 \\
1994 & 151 \\
1995 & 157 \\
1996 & 146 \\
1997 & 115 \\
1998 & 120 \\
1999 & 59 \\
2000 & 157 \\
2001 & 151 \\
2002 & 135 \\
2003 & 141 \\
2004 & 141 \\
2005 & 115 \\
2006 & 120 \\
2007 & 141 \\
2008 & 110 \\
2009 & 177 \\
2010 & 182 \\
Mean & 133 \\
\hline Source: Data Analysis, 2013 \\
&
\end{tabular}


The research findings also indicate that the wettest year in the study period was in 2010 at Kano (Table 3), 2009 at Katsina (Table 4), 2005 at Maiduguri (Table 5), 1981 at Potiskum (Table 6), 1997 at Sokoto (Table 7) and 2010 at Gusau (Table 8 ). These indicate that with exception of Potiskum there was high frequency of wettest year during the last decade of the study period compared with others in the study area. These results were in line with finding of Abaje et al. (2013) who also worked in the study area and reported that the area has been experiencing wetter conditions in recent years.

The data in Fig. 4 indicate both increases and decreases in the mean length of growing season from the extreme north to the southern part of the study area. For instance, the mean length of growing season was 120 days at Maiduguri and increased to 121 days at Potiskum. At Sokoto, it was 121 days and increased to 133 days at Gusau. This observation indicates an increase in mean length of growing season from north to south in the study areas. It also indicates spatial variation in the mean length of growing season among the locations. These findings agree with Aliyu (2009) who observed a downward trend in the duration (length) of the growing season in some locations in northern Nigeria from 1978 to 2007, with a significant variability in most of the stations north of latitude $9^{0} \mathrm{~N}$ in Nigeria.

\section{CONCLUSIONS}

Sudan Savanna Ecological Zone of Nigeria is a zone characterized by scanty rainfall compared with others ecological zones in the country. The spatio-temporal distribution of rainfall decreases from south to north, so as with the length of growing season. The major finding of this study revealed a rather short mean length of growing season of about four months, which corresponded with scanty rainfall experienced in the zone.

The consequences of this observation are shorter grasses, scattered vegetation and low crop yields in the zone. For sustainable agricultural development in this zone, the study recommends that agricultural policies in the area should take into consideration the rather short length of growing season, by providing early-maturing crop varieties. Also, efforts should be made to harvest and conserve rainwater and water from other sources to support crop production in these areas. Farmers should utilize this finding for proper timing of clearing, tilling, planting, weeding and fertilization as well as harvest to meet the target market. Dams should also be constructed to serve for supplemental irrigation across the locations involved in this study to augment water supply in case of long dry-spells during rainfed agriculture.

\section{REFERENCES}

Abaje I.B., Ati O.F., Iguisi E.O. and Jidauna G.G. (2013). Drought in the Sudano-Sahelian ecological zone of Nigeria: implications for agriculture and water resources development. Global Journal of Human Social Science, Vol. 13, Issue 2, Version 1

Adefolalu O.O. (1983). Desertification of the Sahel, Natural Resource in Tropical Countries. University Press, pp .402-438

Aliyu U.T.U. (2009). Impact of the recent trends and variability in the duration of the growing season for food crop production in northern Nigeria. Nig. Met. Soc. Proc. of the Int. Conf. on Climate \& Sustainable Dev., 6-11 ${ }^{\text {th }}$ Dec., 2009, Osogbo, Nigeria, pp. 17-21

Ati O.F., Stigter C.J. and Oladipo E.O. (2002). A comparison of methods to determine the onset of growing season in Northern Nigeria. International Journal of Climatology, 10, 839-848

Anyadike R.N.C. (1992). Regional variations in fluctuations of seasonal rainfall over Nigeria. Theoretical and Applied Climatology, 45, 285-292

Bello N.J. (1996). Investigation the spatial pattern of the characteristics of the onset and cessation of rains in Nigeria, Geography Journal, 53, 113-123

Dagg M. (1965). A rational approach to the selection of crops for areas of marginal rainfall in east Africa. East African Agricultural and Forestry Journal, 30, 296-300

Les J.A. (2006). Atlas of Nigeria, pp.102

Madeoye I.J. (1986). The Statistical Characteristics of Rainfall in Lagos State. Unpublished BSc Project Report, Department of Geography, University of Jos, Jos Plateau State

Obalum S.E., Ezenne G.I., Watanabe Y. and Wakatsuki T. (2011). Contemporary global issue of rising water scarcity for agriculture: the quest for effective and feasible soil moisture and free-water surface conservation strategies. Journal of Water Resource and Protection, 3 (3), 166-175

Odekunle T.O. (2004). Rainfall and length of the growing season in Nigeria. Int. J. of Climatology, 24, 731-742

Oladipo E.O. and Kyari J.D. (1993). Fluctuations in the onset, termination and length of the growing season in northern Nigeria. Theor. Appl. Climatol., 47 (4), 50-241

Olaniran O.J. (1984). The start and end of the growing season in the Niger River Basin Development Authority area of Nigeria. Malaysian Journal of Tropical Geography, 9, 49-58

Omotosho J.B. (1992). Long-range precipitation of onset and end of the rainy season in the west African Sahel, International Journal of Climatology, 12, 369-389

Sawa B.A. and Ibrahim A.A. (2011). Climate change and derived precipitation effectiveness indices in Northern Nigeria: a current synthesis. A Paper Presented at $52^{\text {nd }}$ Annual Conf. of the Assoc. of Nigerian Geographers Held from $14^{\text {th }}$ to $17^{\text {th }}$ February, 2011, at Department of Geography Danfodio University, Sokoto, Nigeria. Sciences and Environmental, 13 (2), 1-10

Shevakuma M. (1988). Prediction rainy season potential from the onset of rains in southern Sahelian and Sudanian climatic zones of West Africa. Agricultural and Forest Meteorology, 11, 295-305

Zargina A.B. (1987). Onset of Effective Rainfall and Characteristics of Dry Spell in Nigerian Savanna. Unpublished BSc Project Report, Department of Geography, Ahmad Bello University, Zaria, Nigeria 